\title{
KITTAP INCELEMESI
}

\author{
Emrah AYDEMİR, Kamu Diplomasisi - Ülkeler - Avrupa Birliği \\ Kurumlar - Uygulamalar \\ (İstanbul, Kalkedon Yayınları, 2018)
}

\section{Pelin SÖNMEZ}

Dr. Öğr. Üyesi, Uluslararası İlişkiler Bölümü, Kocaeli Üniversitesi

\section{Bu kitap değerlendirmesine atıf için}

Sönmez, Pelin, Kitap Değerlendirmesi: "Emrah Aydemir, Kamu Diplomasisi - Ülkeler-Avrupa Birliği Kurumlar-Uygulamalar, İstanbul, Kalkedon Yayınları, 2018”, Uluslararası İlişkiler, Cilt 16, Say1 63, 2019, s. 149-151, DOI: 10.33458/uidergisi.621343

Erişim İçin: https://dx.doi.org/10.33458/uidergisi.621343

\section{Uluslararası İlişkiler Konseyi Derneği | Uluslararası İlişkiler E-Posta: bilgi@uidergisi.com.tr}

Bu makalenin tüm hakları Uluslararası İlişkiler Konseyi Derneği’ne aittir. Önceden yazılı izin almadan hiçbir iletişim, kopyalama ya da yayın sistemi kullanılarak yeniden yayımlanamaz, çoğaltılamaz, dağıtılamaz, satılamaz veya herhangi bir ssekilde kamunun ücretli/ücretsiz kullanımına sunulamaz. Akademik amaçlı alıntılar bu kuralın dışındadır. Yazıda belirtilen fikirler yalnızca yazarına/yazarlarına aittir. UİK Derneğini, editörleri ve diğer yazarları bağlamaz. 


\title{
Kamu Diplomasisi \\ Ülkeler-Avrupa Birliği Kurumlar-Uygulamalar
}

\author{
Emrah AYDEMIR
}

İstanbul, Kalkedon Yayınları, 2018, 313 sayfa, ISBN: 9786057942012

\section{Pelin SÖNMEZ \\ Dr. Öğr. Üyesi, Kocaeli Üniversitesi, İİB, Uluslararası İlişkiler Bölümü, Kocaeli. \\ E-posta: pelin.sonmez@kocaeli.edu.tr}

Kamu diplomasisi pazarlar ve markalar; iletişim kanalları ve medya; eğitim; sanat; spor gibi hayata dair alanlarda kamuoyunda bilgiyi yaygınlaştırmak ve kanaat yaratmak amacını taşır. Bilgi paylaşım hızının, günümüzde ışık hızına yaklaştığı düşünülürse, istenilen algıyı oluşturmak amacıyla bilgi akışını kontrol etmek ve yönlendirmek güç kaynaklarının en büyük kaygılarından biri olarak görülebilir. Bu eser diplomasi, kamu diplomasisi ve yumuşak güç kavramlarını tarihsel perspektif ve kavramsal tartışmalar ile ele alan; farklı ülkeler ile Avrupa Birliği (AB) gibi organizasyonlardan uygulama örnekleri vererek kamu diplomasisinin giderek artan önemine vurgu yapan bir kaynak eser niteliğindedir.

Eserin, iletişim alanında akademik çalışmalar yürüten Aydemir’in medya ve yumuşak güç ilişkilerini anlattığı “Dış Politikada Yumuşak Güç ve Medya” isimli kitabının devamı niteliğinde olduğu önsöz bölümünde ifade edilmiştir. Nitekim eser boyunca Aydemir, kamu diplomasisi ile medya ve iletişim aygıtları arasındaki bağı oldukça başarılı aktarmaktadır. Kitap temel olarak iki kategoriden oluşmaktadır. İlkinde diplomasi, kamu diplomasisinin doğuşu, kamu diplomasisi ve yumuşak güç kavramları ayrı başlıklar olarak anlatılmış; kitabın izleyen başlıklarında ise ülke örnekleri ile birlikte AB’nin kamu diplomasisi uygulamaları ele alınmıştır.

Diplomasi kavramının anlatıldığı başlıkta Aydemir, diplomasinin tanımları ile fonksiyonlarını ve kavramın literatürde karşılık geldiği anlamları aktarmıştır. Özellikle yeni diplomasiye geçilen süreçte, küreselleşmenin de etkisiyle diplomasinin demokrasi ve insan haklarını kapsayan yeni bir boyuta ulaştığını; dolayısıyla artık kamuoyuna taşındığını vurgulamıştır. Kamu diplomasisi yazarın kendi diliyle, "doğru stratejilerin ve uygulamaların devreye girdiği, ihtiyaca yönelik temel mesajların kullanıldığı, ülkelerle ilgili hikayelerin aktarıldığı, devlet dışı aktörlerin ve kamuoylarının sürece dahil edildiği ve stratejik iletişimden yararlanılarak zihin altı vurgusunun söz konusu olduğu çok boyutlu bir paradigma” olarak tanımlanmıştır.

Kamu diplomasisinin aktörleri devlet aktörleri, devlet dışı aktörler, hükümet ve hükümet örgütleri, elçilikler, kültür bakanlığı, dışişleri bakanlığı, kültürel örgütler, diasporalar ve sivil toplum kuruluşları olarak sıralanmakta ve uygulama alanları da eğitim, kültür, lobicilik üzerinden ifade edilmiştir. Kamu diplomasisinin kitle iletişim araçlarını oluşturan gazete, televizyon, sinema, dergi, broşür, kitap gibi yazılı araçlar ile medya ve yeni medya okuyucuya, farklı örnekler kullanılarak 
aktarılmıştır. Ancak özellikle bir yeni medya aracı olarak internet ve internet kullanımına ilişkin artış açıklamalarında kullanılan istatistiklerin güncel olmayışı dikkat çekmektedir.

Yumuşak güç başlığında Aydemir, güç tanımı, yumuşak güç ve sert güç ayrımı ile başlamış ve iki kavramı örnek ülkeler ile somutlaştırmaya çalışmıştır. Ancak güç kavramlarını bu denli yoğun ele alan bir başlıkta "normatif güç" ve "akıllı güç" gibi daha güncel kavramsal tartışmalara sadece dipnotlarda değinilmesi veya kamu diplomasisinin bu yeni kavramlar ile arasındaki bağının kurulmamış olması dikkat çekmektedir. Dünyadaki en önemli yumuşak gücün ABD olarak gösterildiği kitapta, başlığın geri kalanı genellikle ABD örnekleri üzerinden şekillenmektedir.

Eserin sonraki başlıklarında Japonya ile başlayan uygulama örnekleri bulunmaktadır. Kamu diplomasisinde geleneksel kültür ve sanatın yanı sıra Japonya, başlık boyunca pop-kültür araçları olan çizgi romanları ve animasyonları aktif olarak kullanmasıyla öne çıkarılmıştı. Çin Halk Cumhuriyeti’nin bilinen anlamda kamu diplomasisi yürütme çalışmalarına 2004 yılıyla nispeten geç katıldığı belirtilmiş ve bunun nedeni Batı'daki nesnellik ilişkisine karşı olarak Çin'de öznellik ilkesinin hüküm sürmesine bağlanmıştır. Hindistan'ın kamu diplomasisi faaliyetlerinin uluslararası politikada büyük bir rol alamadığı tespiti yapılmış ve bu durum ekonomik büyüme, politik, istikrar ve bölgesel barış dinamiklerinin aynı oranda uyumlu olmamasına bağlanmıştır. Aydemir, Bollywood film endüstrisinin bir yumuşak güç olmadığı, sektörel bir başarı olduğu ve ülke imajına bu anlamda katkı sağlamadığı saptamasını gerekçelerini tatminkar şekilde sıralayarak yapmıştır. Kore Cumhuriyeti başlığında Güney Kore'nin özellikle "Hallyu” olarak bilinen pop kültürü ihracındaki başarılarıyla yumuşak güç konusunda dünyada önde gelen isimlerden biri olduğu belirtilmiştir.

Rusya Federasyonu uygulamalarında Aydemir, Sovyet sonrası dönemde Rus politikacıların yumuşak güç kavramını yanlış yorumladıklarını; kamu diplomasisi alanında çaba göstermekle birlikte Batı ile yürütülen diyalogda açık ve tutarlı olunamadığını ve dünya için Rusya’nın sahip olduğu enerjiyi politik ve ekonomik bir araç olarak kullanabileceği endişesinin giderilemediğini belirtmiştir.

Türkiye'deki kamu diplomasisi uygulamalarının analizine yumuşak güç alanında Türkiye’nin farklı olduğu saptaması ile başlanmıştır. Türkiye’nin yumuşak gücünü bölgesel alanda göstermek için kullanması ve yumuşak güç araçlarını yalnız dini, kültürel ve tarihi bağlara indirgemesi vurgulanmıştır. Aydemir'in Türkiye'nin kamu diplomasisi alanında son yıllarda uygulamaya koyduğu umut vaat eden bir eğitim girişimi olarak Mevlana Değişim Programı́na değinmesi bu alanda güncel gelişmeleri okuyucuya göstermesi bakımından önemlidie.

Son yıllarda TRT’nin açtı̆g kanallar veya Türk dizilerinin dünyada seyrediliyor olmasına yönelik olarak Aydemir, son derece başarılı bir tespit yaparak bunların kamu diplomasisi faaliyetleri olarak görülebilmesi için dış politika hedeflerine ulaşmada bir kamuoyu hareketine yol açıp açmadığına bakılması gerektiğini belirtmiştir. İsrail uygulamalarında yumuşak güç kaynaklarının zenginliği ile bilinen İsrail>in 1967 Savaşı sonrası küresel imajının kötüye gitmesine değinilerek Yahudi Diasporası́nın desteği ile "hasbara" olarak adlandırılan "açıklama" temelli kamu diplomasisi çalışmaları anlatılmıştır.

Almanya, 1960’lı yıllardan bu yana dış politikasında kamu diplomasisini “üçüncü ayak” olarak başarılı bir şekilde kullanan bir devlet olarak gösterilmiştir. Fransa’nın yumuşakgüç ve kamu diplomasisi kaynakları Fransızca için kullanılan "La Francophonie”, Institut Français, Alliance Française ve France 24 TV kanalı gibi medya aygıtları olarak sıralanmıştır. Üst düzey bir kamu diplomasisi yürüttügü 
belirtilen İtalya’da özellikle kültürün önemli bir yumuşak güç varlı̆ğ olarak kullanması vurgulanmıştır. İspanya için en önemli yumuşak güç kaynağının dünyada 570 milyondan fazla insan tarafindan kullanılan İspanyolca olduğu, bu amaçla kurulan Instituto Cervantes' in etkin bir kamu diplomasisi aktörü olabildiği vurgulanmıştır. Portekiz başlığında dil unsuru, tıpkı İspanya'da olduğu gibi, en önemli yumuşak güç kaynağı olarak gösterilmiştir. Birleşik Krallık ise, önceki örneklerde görüldügü gibi, dil unsurunun en önemli yumuşak güç unsuru olduğu bir ülke niteliğindedir ve kamu diplomasisi çalışmaları bakımından 1914'e kadar giden dönem içerisinde tecrübe ve birikime sahip bir ülkedir.

ABD bir sonraki başlıkta detaylı bir şekilde ele alınmış ancak kitabın teorik kısmında da ABD uygulamalarına sıkça yer verilmiştir. ABD’nin popüler görüntüsünün çok güçlü olduğu ve bu gücün global kültürün merkezinde olduğu belirtilerek ABD’nin yumuşak gücü için “ardında demir bir yumruk olan yumuşak bir eldiven” benzetmesi kullanılmıştır. Diğer yandan, söz konusu yumuşak güce zarar veren olaylar 11 Eylül olayları ve El- Kaide ile Küba>nın Guantanamo Körfezinde teröristleri alıkoyduğu gözaltı tesisi olarak gösterilmiştir. Anlatımında Aydemir, tarihsel perspektif ve olaylar üzerinden ABD’nin kültürel emperyalizmi ve hegemonik gücünü okuyucuya sunmuştur.

Brezilya uygulamalarında ülkenin sert gücünün olmadığı, ancak Brezilya>yı yükselten esas unsurun yumuşak güç olduğu ve BRICS, Mercosur gibi uluslararası örgütlere üyeliğinin yumuşak güç için önemi vurgulanmıştır.

AB'nin ele alındığı son başlıkta onun gücü ile ilgili J. Nye>nin yumuşak güç saptamasına değinilmiş ve $A B$ 'nin dış politika stratejisi olarak demokrasi geliştirme misyonuna yer veriliyor. Aydemir, AB'nin uluslararası gücünün tek taraflı zorlamadan ziyade ikna ve işbirliğine odaklı olduğu savunulmuştur. $\mathrm{AB}$ kamu diplomasisi uygulamaları olarak $\mathrm{AB}$ 'nin Topluluk programları ve projeler gösterilerek söz konusu uygulamaların yer aldığı politikalar açıklanmıştır. Burada Aydemir, AB'ye yönelik kamu diplomasisi stratejisini anlatırken algılama ve düşünmenin ortak hale getirilmesi olarak açıklanan zihin paylaşımı kavramını kullanmış ve bu düşünceyi aktarırken değerler Avrupa'sının yarattığı kendine has güç türünü anlatan normatif Avrupa kavramı ve güç ilişkisine sadece dipnot içerisinde değinmiştir. Kamu diplomasisini $\mathrm{AB}$ çapında yürüten kurumlar olarak $\mathrm{AB}$ Ulusal Kültür Merkezlerine, $A B$ Dış İlişkiler Servisine ve $A B$ Delegasyonlarına yer verilmiştir. Ancak genel bir tespit yapmak gerekirse $A B$ başlığı, bir uygulama örneği olarak kitaba adını verecek kadar detaylı incelenmemiştir. Örneğin medya ve iletişim boyutu hiç ele alınmamış ve Erasmus+ Programı gibi büyük bütçeli Topluluk programlarının kamu diplomasisi bakımından yarattığı etki okuyucuya aktarılmamıştır.

Bu eser, teorik temeller bakımından doyurucu bilgiler içermekte, uygulama örnekleri açısından çeşitlilik arz etmekte ve konu olarak Türk literatüründe çok «popüler» olmayan bir alana ışı tutarak Türk yazını için önemli bir katkı sunmaktadır. 